\title{
People Seeking Asylum in Australia and their Access to Employment: Just What Do We Know?
}

\author{
Caroline Fleay, Anita Lumbus and Lisa Hartley \\ Curtin University
}

\begin{abstract}
Public and political claims about the employment of people from a refugee background in Australia do not always reflect the research findings in this area. For example, recent claims by a senior Coalition Government Minister about people seeking asylum who arrived to Australia by boat during the previous Labor Government's terms in office (2007-13) posit that many have limited employment prospects. However, given there is little research or government reporting on the experiences of asylum seekers who arrived during this time, and none that focuses specifically on their employment, there is no evidence to support this. A review of research on the employment experiences of people from a refugee background, and Australian policies, suggests a more nuanced picture. This includes research that found while initially people from a refugee background are more likely to be unemployed, have temporary jobs and lower incomes than other newly arrived immigrants, over the longer term second-generation refugees have higher levels of labour market participation than the general population and refugees and their families make significant economic and community contributions to Australia. Research also highlights that refugees may experience a range of barriers to accessing employment, including discrimination, and a review of Australian policies indicates these are likely to have exacerbated some of these barriers for asylum seekers who arrived to Australia by boat. In addition, given previous findings that public attitudes can be influenced by representations made in public and political discourses, the public statements of senior Ministers may be further deepening barriers to accessing employment faced by asylum seekers who arrived by boat.
\end{abstract}

\section{Introduction}

The employment prospects for people from a refugee background in Australia periodically emerge as a site of public and political contention. However, claims made by some media commentators and Members of Parliament do not reflect the research findings in this area. For example, during a television panel discussion in February 2016, Sydney radio broadcaster Neil Mitchell claimed that there was a 97 per cent unemployment rate for refugees in Australia (ABC 2016). While later acknowledging that he meant to say the unemployment rate was 93 per cent, the study he cited as evidence (Jenkinson, Silbert, De Maio \& Edwards 2016), does not make any such conclusion (Hartley \& Fleay 2016). Erroneously citing the 
same study, Minister for Immigration Peter Dutton claimed in May 2016 that many refugees arrive to Australia illiterate and innumerate (see Ramsay \& Fiske 2016) and that if more refugees were accepted by Australia than the current quota, they “ "would be taking Australian jobs”' and, paradoxically, many “"would languish in unemployment queues”' (quoted in Bourke 2016).

People who come to Australia by boat to seek asylum have been subjected to particular contention in the public domain (Rowe \& O’Brien 2014), including in relation to their employment prospects. For example, in a May 2015 interview arguing that greater efforts were needed to 'integrate' asylum seekers who had arrived to Australia by boat during the previous Labor Government’s terms in office (2007-13), the former Social Services (and former Immigration) Minister Scott Morrison suggested that many would not find employment. Morrison claimed that 'many' asylum seekers who had arrived during the term of the Labor Government 'were poorly educated, had no English, hailed from very different cultural backgrounds and had limited economic opportunities’ (Maley 2015). Without policies that actively 'engaged' this group, he warned that their next generation may become 'marginalised from mainstream life': ““At best, these consequences are long-term unemployment and welfare dependence and at worst gangs, violent crime and even terrorism”' (quoted in Maley 2015).

While Morrison's comments acknowledge that government policies can play an important role in enabling the effective settlement of refugees, he ignores that some policies imposed on asylum seekers who arrive by boat have prevented their employment. As with Dutton's recent comments, Morrison's claims about access to employment were also made without the provision of supporting evidence. Given that political discourse has been found to play an influential role in producing and reproducing prejudice and racism towards groups constructed as the 'other' (van Dijk 1997), Ministers' comments (and those of others in the public domain) need interrogation. In this paper, in recognition of the particular attention given to people who come to Australia by boat, we focus on the claim about the limited employment prospects of the 'many' asylum seekers who arrived by boat since 2007.

The term asylum seeker refers here to a person who has arrived to a country of asylum but whose refugee status is yet to be determined. According to the United Nations (UN) Convention Relating to the Status of Refugees (Refugee Convention), a person is found to be 
a refugee if it is considered likely they would face persecution in their home country due to their race, religion, nationality, membership of a particular social group or political opinion.

As at the time of writing (May 2016), there is no published research or government reporting that specifically documents the employment experiences of asylum seekers in Australia who arrived by boat between 2007 and 2013. Much of the research of the employment experiences of people from a refugee background in Australia focuses on those who arrived under the offshore component of the Refugee and Humanitarian Program (RHP). As in research conducted in other industrialised countries (Connor 2010), Australian studies have found that people from a refugee background are more likely to be unemployed, have temporary jobs and lower incomes than other newly arrived immigrants (Hugo 2011). However, there are many valid and interrelated factors that underpin these findings, including that the data are influenced by recency of arrival and the relative youth of the population (Hugo 2011), lower levels of English proficiency and employer discrimination (Colic-Peisker 2009; Marston 2004). Despite such constraints, Australian and international research highlights the skills, talents, drive and entrepreneurship that people from a refugee background bring to the host society and the economic and community contributions they make over the longer term (Betts et al. 2014; Hugo 2011).

We explore these findings and the relevant research in other industrialised countries, the Australian policy landscape, and the limited available research about asylum seekers who arrived to Australia by boat since 2007, in order to critique the claims of their limited employment prospects. In addition, we discuss the literature that explores the influence of political discourses on community attitudes to asylum seekers, to highlight the impacts that ministerial statements may have on broader Australian community perceptions of asylum seekers, including potential employers. From this, we outline the conclusions that can be drawn in relation to people seeking asylum and their employment prospects in Australia, and where further research is needed.

\section{Policy Overview}

Asylum seekers arriving by boat to Australia have been subjected to punitive policies over the past few decades (Rowe \& O’Brien 2014, p. 172). This is in direct contrast to policies that apply to people from a refugee background who do not arrive by boat. While all people 
accepted as refugees by Australia are done so under the RHP, the program has offshore and onshore components. The offshore component makes resettlement visas available to people recognised as refugees who are not in Australia. The onshore component is for people who arrive to Australia without a valid visa (predominantly those who arrive by boat), or with a valid visa and then apply for refugee status. While an annual quota is set by the Australian Government for this component, since 1996 a link has been made between the onshore and offshore components. This means that an increase in visa numbers granted to people found to be refugees who arrived onshore results in a decreased number of visas offered to offshore refugees (McKay, Thomas, \& Kneebone 2012).

Punitive policies that apply to asylum seekers who arrive to Australia without a valid visa include being subject to mandatory detention while their refugee claims are processed. Since this policy was enshrined in federal legislation in 1992, other punitive policies have also been adopted. Of most relevance here are those of the former Labor Government (2007-13) and the current Coalition Government. From 2007 to 2014, 52,106 people arrived to Australia by boat seeking asylum (Phillips 2015a), most having fled Afghanistan, Iran, Pakistan, Sri Lanka or Iraq (Phillips 2015b). Up until the Department of Immigration and Border Protection suspended the processing of refugee claims of those who arrived by boat following the Coalition Government's election in September 2013 (RCOA 2014), the Department's statistics from the previous five financial years show that 95 per cent were found to be refugees and granted protection visas (Phillips 2015b).

While the Labor Government won the November 2007 election on a platform that included more humane asylum seeker policies than those of the previous Coalition Government (Evans 2008), punitive policies were soon introduced in response to the increasing numbers of boat arrivals. From 2009 Australia’s immigration detention network was extended to detain increasing numbers of asylum seekers for lengthy periods of time. While the Labor Government finally released the majority of men, women and children from detention into the community in 2011-2012 (Bowen 2011), many had been detained for much more than a year by this time (Department of Immigration and Citizenship 2011). They were released and either issued with a bridging visa that included the right to work, or placed into 'community detention' which meant greater access to accommodation and support services but without the right to work. 
Further punitive polices were adopted by the Labor Government as numbers arriving by boat continued to increase. Asylum seekers who arrived after 13 August 2012 were sent to the reopened sites of immigration detention on Nauru and Papua New Guinea's Manus Island (first established by the Howard Coalition Government in 2001 and closed by the Rudd Labor Government in 2008). As more asylum seekers continued to arrive to Australia by boat than could be sent to the regional sites of detention, increasing numbers were held in Australian immigration detention centres. In November 2012 the Labor Government declared that all people who had arrived by boat since 13 August 2012 and not been sent to Nauru or Manus Island could be released from Australian immigration detention centres into the community, but with limited entitlements (Cullen 2012).

Most who arrived by boat after 13 August 2012 and were released from detention were issued a temporary bridging visa $\mathrm{E}$ (BVE). This visa allows asylum seekers to remain lawfully in the community while they wait for their refugee claim to be processed. But it had a condition attached that denies the right to work and only allows access to minimal financial assistance (89 per cent of the national welfare payment for those in severe financial hardship). While BVE holders are entitled to study, they must pay international student fees, and they do not have access to English as a Second Language (ESL) classes provided under the RHP. Instead they have only been able to access an abridged version of these classes (Hartley \& Fleay 2014).

These policies continued after the election of the Coalition Government in September 2013, and further restrictions were imposed. At the end of January 2015, there were 26,168 asylum seekers who had arrived by boat and were living in the community with limited entitlements (Department of Immigration and Border Protection 2015). The majority had arrived after 13 August 2012 and continued to be denied the right to work. While those who arrived before this date were issued with BVEs that did allow the right to work, many of their visas had lapsed by this time. This meant that they too no longer had the right to work. While the authors have received reports in 2016 from some asylum seekers that visas are now being renewed, it is unclear when all will be reissued. In addition, visa renewal now requires a 'Code of Behaviour' to be signed. This allows for the cancellation of the visa if the holder has criminal charges laid against them, they are considered to engage in 'antisocial' behaviour, or they do not cooperate with all 'reasonable requests' from the Department of Immigration and Border Protection (Morrison 2013). 
In March 2015 the Department finally re-commenced the processing of asylum seekers’ refugee claims. However, the Coalition Government has denied access to funded migration agent assistance for the majority of asylum seekers who arrived by boat. This means that many are now forced to prepare and present their refugee claims to the Department with minimal or no legal assistance. Federal legislation in December 2014 has also introduced an expedited claims process and significant limitations on the capacity for decisions to be independently reviewed. In addition, only temporary protection visas will be issued to those recognised as refugees, which will include the right to work but not the right to family reunion nor travel outside of Australia (RCOA 2015).

Given the processing backlog faced by the Department, it is estimated that it will be at least three years before all asylum seekers' claims will be finalised. In the meantime, some policy shift in relation to the right the work is evident. As part of a deal to ensure cross-bench support for the government's legislation in December 2014, the Coalition Government announced that the Minister for Immigration and Border Protection could allow asylum seekers living in the community the right to work while they wait for their claims to be finalised (Yaxley, Norman \& Gul 2015). While this process has been administratively difficult, by September 2015 there were reports that 22,800 asylum seekers had finally been granted the right to work (Toscano 2015).

Policies imposed on asylum seekers who arrived by boat have had implications for their access to employment. Periods of time spent in immigration detention, and that those arriving after 13 August 2012 were denied the right to work for several years, are the most obvious policies that have had a detrimental impact on access to employment. We now turn to the relevant research on employment and people from a refugee background to consider what conclusions may be drawn from their findings in relation to the employment of asylum seekers who arrived since 2007.

\section{Literature Overview}

While some studies have explored the employment experiences of refugees both in Australia and elsewhere, there are few that focus on the employment experiences of asylum seekers who arrived to Australia by boat. The following provides an overview of the findings of 
Australian studies that do include asylum seekers as participants, and other studies of relevance, and draws some tentative conclusions as to the employment prospects of those who arrived by boat since 2007 as well as where further research is needed.

\section{Skills and Employment Experiences of Asylum Seekers upon Arrival to Australia}

While little has been documented about the skills and employment experiences of asylum seekers who arrived to Australia by boat since 2007, a number of earlier studies conducted a skills audit of refugees in Australia, including people who arrived by boat. These studies indicate that at least some asylum seekers who arrived to Australia by boat came with significant employment skills and experiences. For example, Marston (2004) interviewed 39 men and 12 women from a refugee background who had arrived by boat, and fifteen service providers in Victoria in 2002 and 2003. Most of the refugees interviewed were living in the community following detention for more than two years. More than half were unemployed, a quarter studying and a quarter employed in mostly part time, casual or temporary work. However, the study found that 14 of the men had arrived to Australia with high levels of education, and professional backgrounds such as teaching, engineering and information technology (Marston 2004).

On a smaller scale, Scull and Woolcock (2001) found high levels of education but great variation in skills and experiences in a study of 27 refugees in Brisbane who had spent time unemployed, including twelve refugee men and one woman on temporary protection visas from Iran, Iraq and Afghanistan who had arrived by boat. Their time in detention was considered as time unemployed. Their variation in skills and experiences appears to have depended on the life stage of participants who were aged from 22 to 53 . As such, some were starting out in their working life while others had left their home countries with established careers (Scull \& Woolcock 2001).

While it is not clear if any of the participants in another study had arrived by boat, its findings similarly indicate that asylum seekers with substantial skills and experience do arrive to Australia (Croucher \& Dutertre 2007). The study involved an audit of 211 asylum seekers on BVEs without work rights and highlighted that many had substantial skills, tertiary qualifications and experience prior to coming to Australia. This included 16.5 per cent with a university qualification and 32 per cent with a trade or semi-professional background (Croucher \& Dutertre 2007). 
Very little is known about the previous employment of asylum seekers who arrived to Australia by boat since 2007, although two small studies indicate that at least some who arrived from this time had considerable skills and experiences. One study exploring the experiences of asylum seekers who arrived by boat in 2010-11 found that four of the eleven participants had arrived to Australia with building construction employment experience, two with hospitality management experience, one with information technology qualifications and experience, and another with engineering qualifications and experience. All had endured lengthy periods of time in immigration detention (between 15 and 21.5 months) during which they were unable to utilise their employment skills (Fleay, Hartley \& Kenny 2013, p. 481). Another study discussing the experiences of asylum seekers who arrived by boat since 13 August 2012 found that most of the 29 participants 'had employment and/or higher education study experience prior to arriving in Australia’ (Hartley \& Fleay 2014, p. 17).

As outlined earlier, however, those who arrived by boat since 13 August 2012 and were released from immigration detention into the Australian community were denied the right to work until at least 2015. Thus, for those who arrived during this time, upon their release from immigration detention they did not have the legal capacity to try to access employment that may have utilised their skills and experience.

\section{Downward Occupational Mobility and Deskilling}

Despite the arrival to Australia of people from a refugee background with significant employment skills and experience, and some with high-level educational qualifications, a recurring theme in the literature is that they experience downward occupational mobility and deskilling, particularly in the early years of settlement (Hugo 2011). While most of this literature focuses on refugees who arrived to Australia as part of the offshore component of the RHP, one study that included asylum seekers who arrived by boat made similar findings.

One example of the Australian studies that focused on the experiences of offshore refugees is Correa-Velez, Barnett and Gifford (2015). Their longitudinal study highlighted the problem of downward mobility as many of the 233 refugee participants had tertiary qualifications and professional backgrounds yet 95 per cent worked in manual labour roles in Australia. Another study of offshore refugees found that those employed tended to be younger with stronger English skills, yet worked in lower paying positions (Australian Survey Research Group 
2011). Despite low unemployment in Australia and skill shortages in a number of industries, Colic-Peisker (2009) found that 150 offshore refugees of working age with English language skills who were employed or looking for work, with most having been in Australia for more than five years, were similarly concentrated in low skilled areas of work with poor pay and insecure conditions.

As part of a large study on the contribution of humanitarian entrants to Australia, Hugo (2011) assessed the employment experiences of more than 600 first and second generation people from a refugee background. He found they face institutional and discrimination barriers to participation in the formal labour market, with this being the case even if English language skills and education are controlled, and that their employment is 'disproportionately concentrated in low income sectors' (2011, p. xxiv). Hugo also concluded, however, that while refugees worked in unskilled roles they were filling labour gaps not filled by other migrant groups (2011, p. xxiv).

A number of studies in other industrialised countries have made similar conclusions. A recurring theme in the UK literature is the high levels of education among forced migrants, although this was dependent on country of origin with migrants from Zimbabwe in particular having high education levels (Bloch 2006; Doyle 2009). Many forced migrants worked in professional roles in their home country yet were unable to enter the job market as professionals/specialists in the UK, and had experienced insecure, poorly paid employment and deskilling.

The respondents of a Canadian study of more than 500 adults with refugee status similarly found high levels of education, including women who represented more than half of the interviewees (Krahn, Derwing, Mulder \& Wilkinson 2000). While the majority had been employed after arriving in Canada, they were underemployed in temporary and part time roles at higher rates than the Canadian population, and experienced downward occupational mobility (Krahn, Derwing, Mulder \& Wilkinson 2000). Jackson and Bauder (2013) interviewed 17 refugee claimants in Canada and also found that their employment opportunities were restricted to short term work, including in the informal sector, despite participants having resided in Canada for many years. 
While most of the relevant Australian studies have focused on refugees who arrived through the offshore component of the RHP, their findings are supported by Marston's (2004) study that included refugees who arrived by boat. The refugee participants in his study tended to be concentrated in low skilled roles in Australia, even though some had arrived to Australia with high levels of skills, education and experience (Marston 2004). In the absence of research about the employment experiences of asylum seekers in Australia who have more recently arrived by boat, the findings of the studies outlined here suggest they may similarly experience downward occupational mobility and deskilling. Fears of deskilling were expressed by some of the interviewees in Hartley and Fleay's (2014) study of asylum seekers without the right to work who were worried that their skills would fade. Given Hugo's (2011) finding that deskilling is a major factor leading to the unemployment of refugees, government policy that allows for the long-term detention of asylum seekers, and policy that has denied the right to work for thousands of asylum seekers who arrived to Australia since 13 August 2012, is likely to have compounded other barriers they may face in accessing employment.

\section{Barriers to Employment for Asylum Seekers and Refugees}

Studies focused on the experiences of people from a refugee background both in Australia and other industrialised countries suggest that people who arrived to Australia by boat to seek asylum since 2007 may face further barriers to accessing employment. Australian studies that highlight these barriers include those focused on the experiences of offshore refugees as well as some that include asylum seekers who arrived by boat.

A commonly cited barrier in the Australian literature is the lack of Australian work experience (Colic-Peisker 2009; Marston 2004; Scull and Woolcock 2001), while Marston (2004) also highlights the lack of qualifications recognition. Both Hugo (2011) and Marston (2004) identified limited English language skills as a further barrier faced by refugees and asylum seekers to finding employment in Australia, although Correa-Velez, Barnett and Gifford (2015) found that English language proficiency and overseas skills recognition were not predictors of employment in their study. Many of the 233 offshore refugee men in south east Queensland interviewed in this study worked in low status roles where strong English language skills were not necessary. Australian studies also highlight that women can experience additional barriers in searching for employment due to family commitments, including not having the assistance of an extended family network or access to affordable childcare (Wilmsen 2013, p. 256). 
Being granted temporary protection visas compounded the barriers to employment experienced by refugees who arrived to Australia by boat during the Coalition Government's 1996-2007 term in office (Marston 2004). Similar policy has had an impact on access to employment for asylum seekers who arrived to Australia more recently by boat. Fleay, Hartley and Kenny found that most of the eight asylum-seeker men they interviewed who were living in the community in 2012 on a bridging visa 'identified the temporary status of being on a BVE as a significant barrier to finding work' (2013, p. 485).

Studies in other industrialised countries highlight similar barriers. For example, focusing on first generation refugees in the Netherlands, De Vroome and Van Tubergen (2010) accessed national survey data from more than 3,000 respondents to consider their employment and occupational status. Access to post-migration education and work experience, proficiency in the language, and 'bridging social capital' or the connections made with the host community, were found to improve chances of employment. Conversely, health problems and a longer stay in a reception centre were associated negatively with economic integration (De Vroome \& van Tubergen 2010). UK studies highlight the importance of providing tailored support to increase chances of employment and the need to address barriers such as discrimination, removing the legal barrier to work for asylum seekers and recognition of qualifications from overseas (Bloch 2008, p. 34).

Given that asylum seekers who arrived to Australia since 13 August 2012 have endured at least several years without the right to work, effectively limiting their capacity to gain local work experience, and have had minimal access to English language classes, the studies outlined here suggest that government policy has contributed to barriers to accessing employment. The findings above also suggest that remaining on a temporary visa even after being granted the right to work is a further barrier to accessing employment. While many who arrived between 2007 and 13 August 2012 were finally granted permanent visas and the right to work, many had been subjected to lengthy periods of immigration detention and thus they too have had their capacity to gain local work experience limited.

Prejudice, Discrimination and the Influence of Public Representations about Asylum Seekers Australian studies also highlight that discrimination can be a barrier to the employment of people from a refugee background, and that public attitudes can be influenced by 
representations made in public and political discourses. It is difficult to assess the presence of discrimination as it is often based on how people perceive they are being treated (ColicPeisker \& Tilbury 2006). Discrimination can also be structural or institutional, for example, the lack of qualification recognition for refugees. However, while acknowledging the complexities in identifying discrimination, it has been considered a significant barrier for refugees in Australia, preventing their upward mobility (Hugo 2011, p. 27).

Colic-Peisker found that structural discrimination 'reinforced by mainstream prejudices and negative stereotyping of racially and culturally different immigrants and refugees by employers' was a barrier to labour participation and led to poor labour market outcomes (2009, p. 67). In her study, refugees of Middle Eastern background, predominantly Iraqis, had the highest rates of unemployment despite having the highest level of education among the three groups in this study. They also reported the most discrimination in the job market (Colic-Peisker 2009, p. 74).

In Canada, Jackson and Bauder (2013) found that public discourses were perceived by 17 asylum-seeker participants to contribute to barriers to their employment. The public discourses of the 'bogus refugee' and 'queue jumper,' perpetuated by the media and politicians, were perceived by the participants to create an environment of hostility and were partly attributable to their employment in 'refugee jobs’ (Jackson \& Bauder 2013). The 'institutionalised under-utilisation of their skills and experience’ (p. 377) was considered by those interviewed to reinforce public narratives that viewed refugees as having a 'particular place' in the labour market, leading to their employment in jobs considered undesirable to the local population.

Other research explores the influence on public attitudes of representations made in public and political discourses about people seeking asylum. Some studies have sought to understand how 'powerful' elites, including politicians, shape public opinion through discursive frameworks of the 'other' and how the mechanisms of such discourse may produce and reproduce prejudice and racism. For example, van Dijk (1997) identified a number of discursive mechanisms used by politicians in Europe and Northern America to justify prejudice, racism and the negative treatment of immigrants. This includes 'positive selfpreservation', where the nation is constructed in a positive light; for example, having a long tradition of being 'hospitable' and 'fair' while discussing the importance of restricting 
immigration (van Dijk 1997; see also Goodman 2008). It also includes 'negative-other presentations', where migrants are constructed in a negative light; for example, when people from a refugee background are positioned as a security threat (Suhnan, Pedersen \& Hartley 2012) or illegitimate/non-genuine (Pedersen, Watt \& Hansen 2006).

Other research argues that political discourse that includes negative-other presentations of asylum seekers can negatively impact community attitudes. For example, studies concluded that community members who were more prejudiced against people seeking asylum endorsed the same negative-other representations identified in political discourse, such as 'queue jumpers', 'illegals', and 'not genuine’ refugees (Pedersen, Watt \& Hansen 2006; Suhnan, Pedersen \& Hartley 2012). It should be noted, however, that the relationship between political discourse and prejudice is likely to be bi-directional. That is, politicians can influence the community's prejudice levels; alternatively some people may use political rhetoric to justify their own prejudices (Pedersen \& Hartley 2015). This highlights the powerful role that political discourse can play in producing and reproducing prejudice and racism within the community, which includes potential employers of asylum seekers.

Claims made by the former Minister for Social Services that many asylum seekers will not find work, and the Minister for Immigration's recent claims about employment and refugees more broadly, are examples of negative-other presentations. Given the research findings outlined above, these claims may be reinforcing other negative representations that have been made by politicians of asylum seekers as 'illegitimate', 'illegal' and 'queue-jumpers' (McKay, Thomas, \& Kneebone 2012; Pedersen, Watt \& Hansen 2006; Rowe \& O’Brien 2014). This suggests that such public and political discourse could be contributing to further barriers to employment for asylum seekers who arrived to Australia by boat since 2007.

\section{Economic Impacts of Refugees in Australia}

Public claims that many people from a refugee background, including those who arrived by boat, do not find employment suggest that they are an economic burden to Australia. However, research is scarce on the economic impacts of refugees in Australia and only one exists to our knowledge that focuses on those who arrived by boat (Stillwell 2003).

Some studies highlight the initial negative financial impact of offshore refugees to Australia who do have the right to work. Access Economics (2008) examined the impact of new 
migrants to Australia on the Commonwealth government budget using 'The Migrants' Fiscal Impact Model' with projections over a twenty years period. In contrast to most other migrant groups, offshore refugee entrants were found to have a negative contribution for the first twelve years of settlement in Australia due to their low labour force participation and use of government services (Access Economics 2008). However, the authors noted that it was important to consider the age structures of migrant groups, with offshore refugees representing younger age cohorts compared with the overall Australian population (Access Economics 2008). Of the 2006-07 migrant intake, 43 per cent of offshore refugees were aged $0-14$, compared with 19 per cent of the population, and they would therefore draw on the costs of education and other government services to a greater extent in their earlier years (Access Economics 2008). Another study similarly found that while offshore refugees were more likely to be unemployed after five years of settlement, they were also more likely to be engaged in education and 'strongly focused on creating a new life' (Australian Survey Research Group 2011, p.2).

However, caution is needed when drawing conclusions from findings that highlight initial negative impacts between different migrant groups given that it is 'illogical to compare economic contributions between these groups at one point in time, since they are at different stages of their educational and working lives on average' (Parsons 2013, p. 6). Applying an alternative net present value approach, people from a refugee background may make greater economic contributions in the long term compared to other skilled migrants, as this takes into account the longer working life ahead of someone of younger age and acknowledges that relative benefit will depend on a person's earning capacity (Cully 2012, p. 7).

In a similar vein, a number of studies concluded that the length of time in Australia is a predictor of employment for offshore refugees (Correa-Velez, Barnett \& Gifford 2015; Hugo 2011). For example, Hugo found that while offshore refugees experienced difficulties engaging in the workforce in the initial period of settlement, in the long term many experienced upward mobility and second-generation refugees have higher levels of labour market participation than the general population (Hugo 2011).

Studies have also highlighted particular benefits that refugee employment can bring. Hugo found that the resettlement of offshore refugees in regional areas can address labour shortages and their continued resettlement in these communities has the potential to contribute to 
significant regional growth (2011). This was the experience in the Victorian town of Nhill following the resettlement of 160 Karen refugees in 2010 (AMES \& Deloitte Access Economics 2015). Specifically in relation to people who arrived by boat, Stillwell concluded that Afghan refugees had 'made significant economic contributions' to the New South Wales town of Young (2003, p. 247). In addition, there is growing recognition of the importance of remittances sent by refugees to families in their country of origin for the economic development of these regions (Hugo 2011; Nunn, McMichael, Gifford \& Correa-Velez 2014). Therefore, in the absence of research that explores the economic impacts of asylum seekers who arrived by boat since 2007, the studies outlined here suggest that there may well be positive economic benefits for their resettlement in Australia both for their host country and for their communities in their country of origin.

\section{What Can We Conclude?}

A few tentative conclusions can be drawn from the studies outlined above in relation to the access to employment of people seeking asylum who arrived to Australia by boat since 2007. While little has been documented about their skills and experience, the few small-scale studies there are indicate at least some have come to Australia with considerable skills and qualifications. However, as has been the experience of people from a refugee background more generally, overall they may experience downward occupational mobility and deskilling. Given that people who arrived by boat since 2007 have been subjected to mandatory detention (with some having experienced lengthy periods in detention), and those arriving since 13 August 2012 forced to endure several years without the right to work and minimal access to support services, their deskilling is likely to have been exacerbated. These policies would also have limited the ability of those who arrived by boat since 2007 from gaining work experience in Australia and access to English language programs; further barriers to gaining employment for people from a refugee background that studies have highlighted. The issuing of temporary bridging visas to those who arrived since 13 August 2012 (and who face the prospect of a temporary protection visa should they be recognised as a refugee) is likely to be another barrier to their employment. In addition, given the studies that highlight discrimination can serve to further restrict the employment experiences of people from a refugee background, and that public attitudes can be influenced by representations made in public and political discourses, asylum seekers who arrived since 2007 may face further challenges to accessing employment. 
This suggests that government policies have had a detrimental impact on the ability of asylum seekers who arrived from 2007 to access employment. Integration can be understood as a two way process where both the host country as well as refugees have responsibilities (Phillimore \& Goodson 2006; Strang \& Ager 2010). This means that governments need to enact policies to facilitate rather than impede the ability of people from a refugee background to resettle in the host country, including the provision of services and supports that enable access to employment (Correa-Velez, Barnett and Gifford 2015; Da Lomba 2010).

Further research is clearly needed into the experiences of asylum seekers who arrived by boat since 2007 in relation to accessing employment. This is particularly relevant given that research conducted in Sweden found there were significant differences in the employment and integration of people from various migration categories, including that asylum seekers achieve faster employment integration than resettled refugees (Bevelander 2011). As others have identified, further research is needed into the economic contributions of people from a refugee background more generally (Correa-Velez, Barnett \& Gifford 2015; Parsons 2013), including longitudinal research on employment outcomes (RCOA 2010). Research that focuses on the experiences of women who arrived by boat is also needed. Very few of the studies cited above included interviews with women and only a small number of studies have focused specifically on refugee women's experiences (for example, Casimiro, Hancock \& Northcote 2007). In addition, research into the experiences of asylum seekers that recognises and elevates the diversity of their experiences and the impacts of intersectionality (as Soldatic et al. 2015 argue), would allow for a greater understanding of the complexities of employments experiences to be gained.

In the absence of further research, the former Minister for Social Service's assertion of the need for policies that actively engage asylum seekers cannot be based on assumptions that asylum seekers who arrived to Australia since 2007 have 'limited economic opportunities' (Maley 2015). The employment and language skills of people seeking asylum who arrived by boat since 2007, and their employment status, are largely unknown beyond the few smallscale studies outlined above and anecdotal reporting. But the Minister's claims also ignore the body of research that points to a range of barriers to employment that people from a refugee background have faced, as well as the impacts of government policies on the capacity of people seeking asylum who arrived by boat to access employment. That Labor and Coalition government policies have continued mandatory detention, and denied the right to 
work to thousands of asylum seekers who arrived by boat since 13 August 2012, is particularly pertinent here, in addition to considerations of the impacts on broader community attitudes to asylum seekers by ministerial statements.

The Minister’s public statements about asylum seekers who have come to Australia by boat do not acknowledge the broader impacts of Australian policies on asylum seekers over the past five years. Studies highlight the negative mental health consequences of long term detention (for example, see Newman, Proctor \& Dudley 2013). Another suggests that being forced to live in the community without the right to work, with only minimal financial assistance and access to support services and ongoing uncertainty about their future, also has negative mental health consequences (Hartley \& Fleay 2014). Importantly, there are findings that highlight the positive contribution that gaining employment can make in reducing the experiences of negative mental health for asylum seekers (Fleay, Hartley \& Kenny 2013; Hocking, Kennedy \& Sundram 2015).

There are numerous Australian and international studies that show people from a refugee background are strongly motivated to work and become economically independent (Fleay, Hartley \& Kenny 2013; Hyndman \& McLean 2006; Phillimore \& Goodson 2006). While people from a refugee background may face challenges in accessing employment, for many this is not the case in the long term and especially for their children (Hugo 2011). Refugee employment can also benefit local communities (Stilwell 2003), as well as those in their countries of origin through remittances (Nunn, McMichael, Gifford \& Correa-Velez 2014).

Such positive findings desperately need mentioning in ministerial and other public statements in relation to asylum seekers in Australia.

\section{References}

ABC 2016, Corruption, Penalty Rates and Public Health 2016, Q\&A, 8 February, Accessed 6 May 2016, http://www.abc.net.au/tv/qanda/txt/s4395155.htm

Access Economics 2008, 'Migrants fiscal impact model: 2008 update', Accessed 6 May 2016, http://s3.amazonaws.com/zanran_storage/www.immi.gov.au/ContentPages/2294022.pd $\underline{\mathrm{f}}$

Australian Survey Research Group 2011, 'Settlement outcomes of new arrivals - Study for Department of Immigration and Citizenship’, Accessed 6 May 2016, https://www.dss.gov.au/sites/default/files/documents/01_2014/settlement-outcomesnew-arrival_access.pdf

AMES \& Deloitte Access Economics 2015, 'Small towns, big returns: economic and social impact of the Karen resettlement in Nhill'. Accessed 1 May 2016, 
https://www.ames.net.au/files/file/Research/19933\%20AMES\%20Nhill\%20Report\%20 LR.pdf

Betts, A., Bloom, L., Kaplan, J. \& Omata, N. 2014, 'Refugee economies: Rethinking popular assumptions', Humanitarian Innovation Project, University of Oxford. Accessed 6 May 2016, http://www.rsc.ox.ac.uk/refugeeeconomies

Bevelander, P. 2011, 'The employment integration of resettled refugees, asylum claimants, and family reunion migrants in Sweden', Refugee Survey Quarterly, vol. 30 no. 1, pp. 22- 43. doi: http://dx.doi.org/10.1093/rsq/hdq041

Bloch, A. 2006, 'Emigration from Zimbabwe: Migrant perspectives', Social Policy \& Administration, vol. 40 no. 1, pp. 67-87. doi: http://dx.doi.org/10.1111/j.14679515.2006.00477.x

Bloch, A. 2008, 'Refugees in the UK labour market: The conflict between economic integration and policy-led labour market restriction', Journal of Social Policy, vol. 37 no. 1, pp. 21-36. doi: http://dx.doi.org/10.1017/S004727940700147X

Bourke, L. 2016, 'Peter Dutton says 'illiterate and innumerate' refugees would take Australian jobs’, Sydney Morning Herald, 18 May. Accessed 20 May 2016, http://www.smh.com.au/federal-politics/federal-election-2016/peter-dutton-saysilliterate-and-innumerate-refugees-would-take-australian-jobs-20160517goxhj1.html\#ixzz49Lml9XaZ

Bowen, C. 2011, 'Bridging visas to be issued for boat arrivals, Minister for Immigration and Citizenship Media Release', 25 November, Accessed 5 August 2012, http://www.minister.immi.gov.au/media/cb/2011/cb180599.htm

Casimiro, S., Hancock, P. \& Northcote, J. 2007, 'Isolation and insecurity: Resettlement issues among Muslim refugee women in Perth, Western Australia', Australian Journal of Social Issues, vol. 42 no. 1, pp. 55-69.

Colic-Peisker, V. 2009, 'The visibly different refugees in the Australian labour market: Settlement policies and employment realities', in McKay, S. (ed), Refugees, recent migrants and employment: Challenging barriers and exploring pathways, Routledge, Abingdon, Oxford, pp. 67-83.

Colic-Peisker, V. \& Tilbury, F. 2006, 'Employment niches for recent refugees: segmented labour market in twenty-first century Australia', Journal of Refugee Studies, vol. 19 no. 2, pp. 203-229. doi: http://dx.doi.org/10.1093/jrs/fej016

Connor, P. 2010, 'Explaining the refugee gap: Economic outcomes of refugees and other immigrants', Journal of Refugee Studies, vol. 23, pp. 377-397. doi: http://dx.doi.org/10.1093/jrs/feq025

Correa-Velez, I., Barnett, A. G. and Gifford, S. 2015, 'Working for a better life: Longitudinal evidence on the predictors of employment among recently arrived refugee migrant men living in Australia', International Migration, vol. 53, pp. 321-337. doi: http://dx.doi.org/10.1111/imig.12099

Cullen, S. 2012, 'First asylum seekers arrive on Manus Island', ABC News, 21 November, Accessed 6 May 2016, http://www.abc.net.au/news/2012-11-21/first-asylum-seekersarrive-on-manus-island/4383876

Cully, M. 2012, 'More than additions to population: The economic and fiscal impact of immigration', Accessed 21 December 2015, https://www.dss.gov.au/sites/default/files/documents/01_2014/economic-fiscal-impactof-immigration_access.pdf

Croucher, G., \& Dutertre, S. 2007, 'The right to work for all asylum-seekers: Why depriving asylum-seekers of work rights is Australia's loss', The International Journal of Diversity in Organisations, Communities and Nations, vol. 7 no. 4, pp. 241-247. doi: http://dx.doi.org/10.18848/1447-9532/CGP/v07i04/39396 
Da Lomba, S. 2010, 'Legal status and refugee integration: A UK perspective', Journal of Refugee Studies, vol. 23 no. 4, pp. 415-436. doi: http://dx.doi.org/10.1093/jrs/feq039

De Vroome, T., \& Van Tubergen, F. 2010, 'The employment experience of refugees in the Netherlands', International Migration Review, vol 44, pp. 376-403. doi: http://dx.doi.org/10.1111/j.1747-7379.2010.00810.x

Department of Immigration and Citizenship 2011, 'Immigration Detention Statistics Summary 31 October 2011’, Accessed 7 August 2012, www.immi.gov.au/managingaustralias-borders/detention/facilities/statistics/

Department of Immigration and Border Protection 2015, 'Immigration detention and community statistics summary 31 January 2015, Accessed 12 February 2015, http://www.immi.gov.au/About/Documents/detention/immigration-detention-statisticsjan2015.pdf

Evans, C. 2008, 'New directions in detention, restoring integrity to Australia's immigration system', Seminar Centre for International and Public Law, Australian National University, 29 July.

Goodman, S. 2008, 'Justifying the harsh treatment of asylum seekers through the support of social cohesion', Annual Review of Critical Psychology, vol. 6, pp. 110-124.

Fleay, C., Hartley, L. \& Kenny, M. 2013, 'Refugees and asylum seekers living in the Australian community: The importance of work rights and employment support', Australian Journal of Social Issues, vol. 48 no. 4, pp. 473-493.

Hartley, L. \& Fleay, C. 2014, 'Policy as punishment: Asylum seekers in the community without the right to work', Australian Policy Online, 18 February, Accessed 12 February 2015, http://apo.org.au/node/38122

Hocking, D.C., Kennedy, G.A. \& Sundram, S. 2015, 'Mental disorders in asylum seekers: the role of the refugee determination process and employment', The Journal of Nervous and Mental Disease, vol. 203 no. 1, pp. 28-32. doi: http://dx.doi.org/10.1097/NMD.0000000000000230

Hugo, G. 2011, 'Economic, social and civic contributions of first and second generation humanitarian entrant', Accessed 6 May 2016, http://www.border.gov.au/ReportsandPublications/Documents/research/economicsocial-civic-contributions-about-the-research2011.pdf

Hyndman, J., \& Mclean, J. 2006, 'Settling like a state: Acehnese refugees in Vancouver', Journal of Refugee Studies, vol. 19 no. 3, pp. 345-360. doi: http://dx.doi.org/10.1093/jrs/fel016

Jackson, S., \& Bauder, H. 2013, 'Neither temporary, nor permanent: the precarious employment experiences of refugee claimants in Canada', Journal of Refugee Studies, vol. 27 no. 3, pp. 360-381. doi: http://dx.doi.org/10.1093/jrs/fet048

Jenkinson, R., Silbert, M., De Maio, J. \& Edwards, B. 2016, 'Settlement experiences of recently arrived humanitarian migrants. Building a new life in Australia', Fact Sheet 2016, Australian Institute of Family Studies, Accessed 26 April 2016, https://aifs.gov.au/sites/default/files/publication-documents/bnla-fs1-settlementexperiences.pdf

Krahn, H., Derwing, T., Mulder, M. \& Wilkinson, L. 2000, 'Educated and underemployed: Refugee integration into the Canadian labour market', Journal of International Migration and Integration, vol. 1 no. 1, pp. 59-84. doi: http://dx.doi.org/10.1007/s12134-000-1008-2

Maley, P. 2015, 'Integrate new arrivals or let in crime, terror: Minister', The Australian, 23 May, Accessed 6 May 2016, http://www.theaustralian.com.au/in-depth/communityunder-siege/integrate-new-arrivals-or-let-in-crime-terror-minister/newsstory/24649a8d1f477cca2aaa804767aa1025 
Marston, G. 2004, 'A punitive policy: Labour force participation of refugees on temporary protection visas', Labour \& Industry: A journal of the social and economic relations of work, vol. 15 no. 1 , pp. 65-79.

McKay, F. H., Thomas, S. L. \& Kneebone, S. 2012, “"It would be okay if they came through the proper channels": Community perceptions and attitudes toward asylum seekers in Australia', Journal of Refugee Studies, vol. 25, pp. 113-133. doi: http://dx.doi.org/10.1093/jrs/fer010

Morrison, S. 2013, 'Government implements behaviour code for illegal maritime arrivals in the community', Accessed 20 December 2013, http://www.minister.immi.gov.au/search/cache.cgi?collection=immirss\&doc $=2013 \% 2 \mathrm{~F}$ $\underline{\text { sm210412.xml }}$

Newman, L., Proctor, N. and Dudley, M., 2013, 'Seeking asylum in Australia: immigration detention, human rights and mental health care', Australasian Psychiatry, vol. 21 no. 4, pp. 315-320. doi: http://dx.doi.org/10.1177/1039856213491991

Nunn, C., McMichael, C., Gifford, S.M. \& Correa-Velez, I. 2014, “"I came to this country for a better life": Factors mediating employment trajectories among young people who migrated to Australia as refugees during adolescence', Journal of Youth Studies, vol. 17 no. 9, pp. 1205-1220. doi: http://dx.doi.org/10.1080/13676261.2014.901496

Parsons, R. 2013, 'Assessing the economic contribution of refugees in Australia', Multicultural Development Association, Accessed 6 May 2016, http://apo.org.au/files/Resource/mda_assessing-economic-contribution-refugeesaustralia_2013.pdf

Pedersen, A., \& Hartley, L.K. 2015, 'Can we make a difference? Prejudice towards asylum seekers in Australia and the effectiveness of antiprejudice interventions', Journal of Pacific Rim Psychology, vol. 9, pp. 1-14. doi: http://dx.doi.org/10.1017/prp.2015.1

Pedersen, A., Watt, S., \& Hansen, S. 2006, 'The role of false beliefs in the community's and the federal government's attitudes toward Australian asylum seekers', Australian Journal of Social Issues, vol. 41 no. 1, pp. 105-124.

Phillimore J. \& Goodson, L. 2006, 'Problem or opportunity? Asylum seekers, refugees, employment and social exclusion in deprived urban areas', Urban Studies, vol. 43 no. 10, pp. 1715-1736. doi: http://dx.doi.org/10.1080/00420980600838606

Phillips, J. 2015a, 'Boat arrivals and boat "turnbacks” in Australia since 1976: A quick guide to the statistics', Australian Parliamentary Library, Accessed 26 April 2016, http://www.aph.gov.au/About_Parliament/Parliamentary_Departments/Parliamentary Library/pubs/rp/rp1516/Quick_Guides/BoatTurnbacks

Phillips, J. 2015b, ‘Asylum seekers and refugees: What are the facts?', Australian Parliamentary Library, Accessed 26 April 2016, http://www.aph.gov.au/About_Parliament/Parliamentary_Departments/Parliamentary Library/pubs/rp/rp1415/AsylumFacts\#_Toc413067445

Refugee Council of Australia (RCOA) 2010, 'Economic, civic and social contributions of refugees and humanitarian entrants: A literature review', Report for the Department of Immigration and Citizenship, Canberra, Commonwealth of Australia, Accessed 6 May 2016, http://www.refugeecouncil.org.au/docs/resources/Contributions_of_refugees.pdf

RCOA 2014, 'What happens now that Australia has “stopped the boats”?' Accessed 12 April 2016, http://www.refugeecouncil.org.au/r/spch/140821_UWA.pdf

RCOA 2015, 'Migration and Maritime Powers Legislation Amendment (Resolving the Asylum Legacy Caseload) Act 2014: What it means for asylum seekers', Accessed 12 February 2015, http://www.refugeecouncil.org.au/wp-content/uploads/2015/02/1502Legacy-Caseload.pdf 
Rowe, E. \& O’Brien, E. 2014, “'Genuine” refugees or illegitimate "boat people”: Political constructions of asylum seekers and refugees in the Malaysia Deal debate', Australian Journal of Social Issues, vol. 49 no. 2, pp. 171-193.

Scull, S. \& Woolcock, G.W.E. 2001, 'Creative pathways: Anglicare Refugee and Migrant Services (ARMS) - A skills audit of refugees in Brisbane’, Ipswich Qld: Community Service and Research Centre.

Suhnan, A., Pedersen, A. \& Hartley, L. K. 2012, 'Re-examining prejudice against asylum seekers in Australia: The role of people smugglers, the perception of threat, and acceptance of false beliefs', The Australian Community Psychologist, vol. 24, pp. 79-97.

Soldatic, K., Somers, K., Buckley, A. \& Fleay, C. 2015, “"Nowhere to be found”: Disabled refugees and asylum seekers within the Australian resettlement landscape', Disability and the Global South, Special issue: Disability and Forced Migration, vol. 2 no. 1, pp. 501-522.

Stillwell, F. 2003, 'Refugees in a region: Afghans in Young, NSW', Urban Policy and Research, vol. 21 no. 3, pp. 235-248. doi: http://dx.doi.org/10.1080/0811114032000113635

Strang, A. \& Ager, A., 2010, 'Refugee integration: Emerging trends and remaining agendas', Journal of Refugee Studies, vol. 23 no. 4, pp. 589-607. doi: http://dx.doi.org/10.1093/jrs/feq046

Toscano, N. 2015, 'More than 20,000 asylum seekers receive work rights after years living in forced destitution’, Sydney Morning Herald, 25 September, Accessed 6 May 2016, http://www.smh.com.au/national/more-than-20000-asylum-seekers-receive-workrights-after-years-living-in-forced-destitution-20150924-gjtvnx.html

Van Dijk, T. A. 1997, 'Political discourse and racism: Describing others in Western parliaments' in S. H.Riggins (ed.), The Language and Politics of Exclusion: Others in Discourse. London, Sage, pp. 31-64.

Yaxley, L., Norman, J. \& Gul, J. 2015, 'Temporary protection visas: Senate votes to bring back temporary visas after deal to get children off Christmas Island', $A B C$ News, 5 December, Accessed 12 February 2016, http://www.abc.net.au/news/2014-1205/senate-agrees-to-reintroduce-temporary-protection-visas/5945576

\section{Statement on Conflicts of Interest}

The review process for this article was managed by the Editorial Committee according to the COPE guidelines and the authors, as guest editors for the issue, had no involvement in it. 